Egyptian Poultry Science Journal

http://www.epsaegypt.com

ISSN: 1110-5623 (Print) - 2090-0570 (On line)

\title{
EFFECT OF DIFFERENT LEVELS OF Aspergillus awamori AS PROBIOTIC ON THE PRODUCTION AND EGG QUALITY OF LAYING JAPANESE QUAIL UNDER SUMMER CONDITIONS
}

\section{H. S. Zeweil*, Y. Z. Eid ${ }^{* *}$, S. Zahran*, W. Dosoky*, Salma H. Abu Hafsa ${ }^{* * *}$ and Amal} Girges*

${ }^{*}$ Faculty of Agric. (Saba Basha), Dep. of Anim. and Fish Prod., Alexandria University, Egypt, ${ }^{* *}$ Faculty of Agric., Department of Poultry Prod., Kafrelsheikh University, 33516 Kafr El-Sheikh, Egypt; ***:Department of Livestock Research, Arid Lands Cultivation Res. Instit., City of Scien. Res. and Tech. App., New Borg El-Arab, Alexandria, Egypt.

Received: 18/-11/2015

Accepted: 10/01/2016

ABSTRACT: This experiment was conducted to study the effect of probiotic supplement (contains Aspergillus awamori) on performance, egg production, egg quality and serum blood characteristics of quails. A total of 135 laying Japanese quails were randomly assigned to one of five treatments with three replicates $(n=9$ quails per replicate). The experimental treatments were: the $1^{\text {st }}$ group received a layer basal diet without supplement and served as control. The $2^{\text {nd }}, 3^{\text {rd }}, 4^{\text {th }}$ and $5^{\text {th }}$ groups were fed the control diet supplemented with 250, 500, 750 and $1000 \mathrm{mg}$ Tomoko ${ }^{\circledR}$ (contains Aspergillus awamori)/Kg diet for 12 weeks through summer season. Results indicated that the supplementation of 750 and 1000 $\mathrm{mg}$ Aspergillus awamori/kg diet recorded a significant $(\mathrm{P} \leq 0.05)$ improvement in egg production by 8.4 and $14.9 \%$ and eggs mass/hen/day $(\mathrm{P} \leq 0.05)$ by 5.0 and $10.7 \%$, respectively, as compared to the control. However, aforementioned groups improved feed conversion ratio, but differences were not significant compared to the control. No significant differences were observed in feed consumption and most of studied egg quality (egg, yolk and albumen weights, shell percentage, egg specific gravity, albumen index, and yolk index) among treatments. Laying quails fed with $1000 \mathrm{mg}$ of Aspergillus awamori improved albumen height. Inclusion of Aspergillus awamori led to a greater egg shell weight, whereas egg shell thickness was improved in supplemented groups with 250, 500 and $750 \mathrm{mg}$ Aspergillus awamori/kg diet as compared to the control. Yolk total lipids and total cholesterol was decreased significantly and the lowest value was observed in group given $1000 \mathrm{mg}$ Aspergillus awamori/kg diet. Also, birds fed different levels of Aspergillus awamori in diet had serum low density lipoprotein values significantly $(\mathrm{P} \leq 0.05)$ lower than the control. Malondialdehyde (MDA) level of Aspergillus awamori supplemented groups was significantly lower than the control. However results showed insignificant increase in total antioxidant capacity and significant $(\mathrm{P} \leq 0.05)$ increase in glutathione peroxidase in the Aspergillus awamori groups. In conclusion, the results showed that supplementation of probiotic contains Aspergillus awamori improves performance, egg production, and antioxidant status as a feed additive in the diet of laying quails under summer conditions.

Key Words: Quail, Aspergillus Awamori, Probiotic, Egg production, Summer condition

Corresponding author: hashim_salma@yahoo.com. 


\section{INTRODUCTION}

Heat stress is a prime consideration in poultry production systems and has a profound effect on animal health and productivity (Humphrey, 2006). Heat stress has been shown to influence bird physiology and induce multiple physiological disturbances, such as systemic immune dysregulation, endocrine disorders and electrolyte imbalance (Sohail et al., 2010; Sohail et al., 2012). As the heat load increases, the rise in body temperature results in tissue damage by heat stress-induced production of reactive oxygen species (ROS) (Khan et al., 2012). Reactive oxygen species, which are produced in mitochondria under physiological conditions, are essential for the body to function (Khan et al., 2012); i.e., defense against infectious agents, functioning of cellular signaling systems, and induction of the mitogenic response (Valko et al., 2007). However, ROS are neutralized by the antioxidant system in the physiological state because a higher level of ROS production is potentially harmful to the maintenance of homeostasis (Surai, 2002). Intracellular, ROS are removed by antioxidant enzymes. The most important antioxidant enzymes, which act as catalysts in many important reactions related to antioxidant defense, are glutathione peroxidase (GPX), catalase (CAT), and superoxide dismutase (SOD). These enzymes are localized in the cytosol or mitochondria (Ercal et al., 2001; Pinto et al., 2003).

In recent years, some reports have indicated that heat stress negatively affects intestinal mucosa and microbiota (Burkholder et al., 2008; Quinteiro-Filho et al., 2010). Mucosal defense mechanisms in the small intestine are able to maintain a crucial barrier to microbial invasion yet allow efficient nutrient absorption (Elphick and Mahida, 2005). Damage to the mucosal epithelium can directly affect its barrier function. Conversely, alteration of this protective barrier may leave the host more susceptible to colonization by enteric pathogens (Durant et al., 1999). The intestinal bacterial populations have an important physiological and pathological effect on host. Stable intestinal microflora can protect the host from pathogen colonization by competing for epithelial binding sites and nutrients, strengthening the intestinal immune response, and by producing antimicrobial bacteriocins (Burkholder et al., 2008). Recent research has focused on the effects of probiotics as functional feed additives to influence bird performance, intestinal microarchitecture, and microbial profiles (Fuller, 1989). The use of probiotics has also been proven beneficial in alleviating the adverse effects of heat stress (Eid et al., 2003, 2008; Lin et al., 2006; Sahin et al., 2009). Kaminishi et al. (1999) reported that several strains of Aspergillus produce antioxidative substances. Yokoyama et al. (2001) described detailed identification, classification and phylogeny of the Aspergillus family. Aspergillus awamori, which is called "koji" in Japan and has been used for the processing of shochu (a major distilled liquor in Japan). The products containing Aspergillus awamori have been given GRAS (Generally Recognized as Safe) status from the Food Drug Administration (Bigelis and Lasure, 1987). Quite a few researches have shown the beneficial effects of probiotic in birds exposed to high temperature (Sohail et al., 2010; Deng et al., 2012; Zeweil et al., 2015). Therefore, the aim of the current study was to assess the effects of probiotic feed additive containing Aspergillus awamori on laying performance, egg quality and blood serum lipids of Japanese quail under summer condition in Egypt.

\section{MATERIALS AND METHODS}

The present study was carried out at the Poultry Research Laboratory, Department of Animal and Fish Production, Faculty of Agriculture (Saba 
Basha), Alexandria University, Egypt. The experiment was conducted in summer season and temperature was ranged from $25-30{ }^{\circ} \mathrm{C}$. A total of 135 laying Japanese quail hens, which had been in production for 12 weeks, were randomly distributed into five treatments with three replicates of 9 quails in each in a completely randomized design. The birds were selected on the basis of more than $70 \%$ egg production rate after a two-week observation period. The quails were then fed 1 of 5 diets: a layer basal diet with no supplement and served as control and basal diet supplemented with 250, 500, 750 and $1000 \mathrm{mg} / \mathrm{kg}$ Tomoko® which contains $12.5 \times 10^{4}, 25 \times 10^{4}, 37.5 \times 10^{4}$ and $50 \times 10^{4}$ Aspergillus awamori spores $/ \mathrm{kg}$ diet respectively. Tomoko is the product of Biogenkoji Research Institute - 876-15 Mizobe, Kagoshima, Japan. The basal diet was formulated to meet the birds dietary nutrient requirements (NRC, 1994). The composition of basal diet is shown in Table 1.

All quails were reared in wire batteries under the same managerial, hygienic and environmental conditions. Feed and water were available ad libitum and light regimen was of $16 \mathrm{~h}$ of light (16L: 8D) for three months from July to September. Body weight and feed consumption were recorded weekly. Feed conversion ratio was calculated ( $\mathrm{g}$ feed / g egg). Egg production, number of eggs, egg weights and mortality rate were monitored daily. Egg quality measurements were conducted using an average of 21 eggs from each treatment and were performed through two consecutive days per month. Shell thickness was determined from measurements of the mean thickness at three locations on the egg (air cell, equator and sharp end) using a dial pipe gauge (Mitutoyo, 0.01-20 mm, Tokyo, Japan). Yolk cholesterol was determined by nine eggs from each treatment and measured by the method of Folch et al., (1956) as modified by Washburn and Nix (1974). At the end of the experiment, blood samples were collected from the brachial vein of 3 hens randomly chosen from each group then serum were immediately centrifuged at 3500 r.p.m. for $15 \mathrm{~min}$. and stored at $18^{\circ} \mathrm{C}$ until use. Serum total protein, albumin, total lipids, cholesterol, low density lipoprotein, high density lipoprotein, total antioxidant capacity, glutathione peroxidase and malondialdehyde were calorimetrically determined using commercial kits (Biomerieux, Poains, France). The proximate chemical analysis of diet was determined according to AOAC (2005). Data were analyzed by analysis of variance using the general linear model procedure (Proc GLM; SAS Institute, 1996). For the overall means, data was classified according to 5 treatments and the mean of each treatment was used. Differences among means were determined using Duncan test (Duncan, 1955).

\section{RESULTS AND DISCUSSIONS}

As shown in Table 2, dietary supplementation of probiotic Aspergillus awamori at level 750 and $1000 \mathrm{mg}$ caused a significant $(\mathrm{P} \leq 0.05)$ improvement in egg production by 8.4 and $14.9 \%$ and egg mass/hen/day by 5.0 and $10.7 \%$, respectively, as compared to the control. Body weight gain and egg weight of laying quails fed supplemented diets was not significantly affected by treatments. Probiotic inclusion did not influence the egg weight significantly; this was in agreement with Chen (2003). Balevi et al. (2001) were fed commercial multi strain probiotic to 40-week-old layers and showed no statistically significant differences in egg production and egg weight compared with the control. It should be pointed out that any gain in body weight after commencement of egg production should be minimal as the hen is essentially, at its mature body weight. Kurtoglu et al. (2004) 
showed significant increase in egg production by probiotic supplementation were seen on days 60-90 of their experiment and this may refer to better utilization of feed ingredients as affected with the action of Aspergillus awamori .

It could be noticed that egg weight did not decline by the increase of egg production as a result of adding Aspergillus awamori supplementation in laying quails diets. These results are in agreement, more or less, with those of Zeweil et al. (2010) and Abdel-Azeem (2005), who indicated that egg production, egg weight and egg mass were improved in laying hens fed on probiotic-supplemented diets. The significant improvement in laying rates for birds given supplemented diets with Aspergillus awamori may due to the enzymes secreted by Aspergillus awamori fungi in birds gut which improve and maximize the utilization of feed components, also enabled the good bacteria to compete against the colonization of the E. coli resulting in a better performance due to affecting the intestinal $\mathrm{pH}$ (Mountzouris et al., 2007). Similer results using bacteria as probiotic obtained by Higgins et al. (2008) where oral administration of $10^{6}$ or $10^{8} \mathrm{cfu}$ of Lactobacilli based probiotic significantly reduced salmonella enteritis disinfection but lower dosage of the probiotic had no effect on the bacteria. The positive effect of Tomoko supplementation, observed in the present study is in agreement with the result obtained by Alloui et al. (2013).

No significant differences were observed in feed consumption among treatments. The results showed that the supplementation of 750 and $1000 \mathrm{mg}$ Aspergillus awamori / $\mathrm{kg}$ diet improved feed conversion ratio, but differences were not significant compared to the control. This result agreed with that reported by Mahdavi et al. (2005) who found that using the different levels of probiotic had no significant effects on feed consumption and feed conversion ratio.
Egg quality measurements (egg, yolk and albumen weights, shell percentage, egg specific gravity, albumen index, and yolk index) didn't affected by Aspergillus awamori probiotic supplementation (Table 3). Laying quails fed with $1000 \mathrm{mg}$ of Aspergillus awamori improved $(\mathrm{P} \leq 0.05)$ albumen height. Inclusion of Aspergillus awamori led to a enhancing egg shell weight compared to control. Egg shell thickness in all treatment was higher than control and this showed the positive effects of Aspergillus awamori probiotic supplementation during summer condition. Hosseini et al. (2006) reported that addition of yeast in commercial layer hen diet had not any positive effect on egg shell thickness and egg shell quality. Mahdavi et al. (2005) realized that using the different levels of probiotic had no significant effects on shell thickness. Similarly, Asli et al. (2007), Simeamelak et al. (2013) who stated that egg quality parameters was not significantly difference in the treatments received different levels of probiotic microorganisms, as compared to the control. However, Yousefi and Karkoodi (2007), reported improvement in egg quality, as a result of addition of 100 to $750 \mathrm{mg}$ of probiotic microorganism $/ \mathrm{kg}$ to feed. Güçlü (2011) reported that supplementation of $0.5 \mathrm{~kg} /$ ton probiotic improved $(\mathrm{P} \leq 0.05)$ egg shell thickness. However, Aspergillus awamori supplementation to the diets had insignificant effects on egg weight, egg specific gravity, albumen index and yolk index, on other words, none of the egg quality parameters were negatively affected with the inclusion of Aspergillus awamori in diets comparing to the control.:

It was notably, that significant differences were existed among dietary treatments in the yolk total lipids and total cholesterol which recorded the lowest significantly $(\mathrm{P} \leq 0.05)$ values in the group given 1000 mg Tomoko/ $\mathrm{kg}$ diet (Table 4). The decrease reached to 24.6 for total lipids and $9.1 \%$ for total cholesterol in comparison 
with the control group. The reduction in serum cholesterol and total lipids due to feeding Aspergillus awamori may be due to its metabolic role in the transportation of long chain fatty acids into the metaconderial matrix or $\beta$ - oxidation (Bremer, 1983). The mechanism underlying the cholesterol-lowering effect of Aspergillus could be related to an inhibitor of 3-hydroxyl-3-methylglutarylcoenzyme (HMG-CoA) reductase. It is well known that an HMG-CoA reductase inhibitor (statin) was extracted from a fungus (Endo, 1985). Li et al. (2011) showed significant decrease in egg yolk triglycerides and total cholesterol in the group of laying hens fed diet containing probiotic composed of Bacillus subtillus as compared to the control group. Other researchers observed also beneficial effects of the tested probiotic on egg quality such as a lower cholesterol content, (Awaad et al., 2005; Mikulski et al., 2012).

The effect of Aspergillus awamori on some blood constituents of laying Japanese quails are presented in Table (5). The studied serum constituents (total protein, albumin, globulin, cholesterol, high density lipoprotein and total lipids) for laying Japanese quails fed Aspergillus awamori diets were not significantly affected except of serum low density lipoprotein. Feeding laying quails on Aspergillus awamori supplemented diets resulted in significantly $(\mathrm{P} \leq 0.05)$ lower low density lipoprotein value than those fed the control diet. The results of LDL are consistent with previous results (Saleh et al., 2012) indicating that A. awamori feeding increases the mRNA levels of FAS, ACC and delta- 6 desaturase in chickens. On the other hand, obtained results were in disagreement with those presented by AboMahara (2015) who illustrated that probiotic reduced total cholesterol levels in blood serum as compared to the control group in Japanese quail. Li et al. (2011) showed significant decrease in blood cholesterol in the laying hens fed probiotic diet containing Bacillus subtillus as compared to the control group.

The results presented in Table 5 showed none significant increase in serum total antioxidant capacity in all treated groups compared to control. However, the levels of serum glutathione peroxidase appeared to antagonize the effect of high temperature during summer with significant increase escpecially in the high levels comparing to control group. Heat stress causes increased free radical production (Halliwell and Gutteridge, 1989) and lower the concentrations of antioxidant vitamins and minerals such as $\mathrm{E}, \mathrm{C}, \mathrm{A}$ and $\mathrm{Zn}$ in serum and tissues (Sahin and Kucuk, 2003). Free radicals trigger the metabolic disorder, cell death and growth retardation (Okada, 1996).

By using MDA as a marker of the oxidative stress, we studied the effect of summer conditions and Aspergillus awamori supplement on lipid peroxidation in serum. Exposing laying Japanese quail hens to high temperature conditions during summer season resulted in elevated $(\mathrm{P} \leq 0.05)$ serum MDA as compared to the control group (Table 5); however, supplementation of Aspergillus awamori to antagonize this effect. Stress leads to a generation of free radicals which can damage cell membranes by inducing lipid peroxidation of polyunsaturated fatty acids in the cell membrane (Luadicina and Marnett, 1990), destroying membrane integrity during stress. Results of Li et al. (2011) showed significant decrease in blood MDA in the group of laying hens fed diet containing Bacillus subtillus as compared to the control group.

\section{CONCLUSION}

The results of the present study suggests that (Aspergillus awamori) as probiotic supplementation offers a feasible way to reduce the losses in performance, improves egg production and oxidative status of Japanese quail reared under summer conditions. 
Table (1): Composition and calculated analysis of the experimental basal diets

\begin{tabular}{|c|c|}
\hline \multirow{2}{*}{ Ingredints } & Experimental diets $\%$ \\
\hline & Laying \\
\hline Yellow corn & 59.50 \\
\hline Soybean meal (44 \%) & 22.60 \\
\hline Concentrate $(50 \%) *$ & 10.00 \\
\hline Di-calcium phosphate & 0.40 \\
\hline Limestone & 5.50 \\
\hline Sunflower oil & 1.00 \\
\hline Vit. and min. mix.** & 0.50 \\
\hline Salt $(\mathrm{NaCl})$ & 0.50 \\
\hline Total & 100 \\
\hline Calculated analyses $^{1}$ : & \\
\hline Crude protein, $\%$ & 20.00 \\
\hline ME (Kcal/ Kg diet) & 2903.89 \\
\hline Ether extract, \% & 2.60 \\
\hline Crude fiber, \% & 3.04 \\
\hline Methionine, \% & 0.71 \\
\hline Methionine + cystine, $\%$ & 0.90 \\
\hline Lysine, \% & 1.15 \\
\hline Calcium, \% & 2.58 \\
\hline Av. phosphorus & 0.40 \\
\hline
\end{tabular}

* Concentrate : ME (K cal $/ \mathrm{kg}$ ) 2870, Crude protein 50\%, Crude fiber $1.51 \%$, Crude fat $1.54 \%$, Calcium $4.29 \%$, Phosphorus $2.39 \%, \mathrm{NaCl}$ 0.8\%, Methionine 4.6\%, Methionine \& Cystine 5.38\%, Lysine 3.90\%. ** Each $\mathrm{kg}$ of vitamin and minerals mixture contained: Vit. A, 4,000,000 IU; Vit. D3, 500,000 IU; Vit, E, 16.7 g., Vit. K, 0.67 g., Vit. B1, 0.67 g., Vit. B2, 2 g., Vit. B 6, .67 g., Vit. B12, 0.004 g., Nicotinic acid, 16.7 g., Pantothenic acid, 6.67 g., Biotin, 0.07 g., Folic acid, 1.67 g., Choline chloride, 400 g., Zn, 23.3 g., Mn, 10 g., Fe, 25 g., Cu, 1.67 g., I, 0.25 g.,Se, 0.033 g. and, $\mathrm{Mg}, 133.4 \mathrm{~g}$.

1 According to NRC (1994). 
Table (2): Performance of laying Japanese quails fed diets supplemented with different levels of Aspergillus awamori (Means \pm SE)

\begin{tabular}{|c|c|c|c|c|c|}
\hline \multirow{2}{*}{ Parameters } & \multirow{2}{*}{ Control } & \multicolumn{4}{|c|}{ Tomoko (mg/kg diet) } \\
\hline & & 250 & 500 & 750 & 1000 \\
\hline Body weight gain, (g) & $19.64 \pm 3.45$ & $26.84 \pm 3.70$ & $25.01 \pm 3.48$ & $22.69 \pm 3.29$ & $24.59 \pm 2.25$ \\
\hline $\begin{array}{l}\text { Egg production \%, hen- } \\
\text { day }\end{array}$ & $74.90 \pm 0.91^{\mathrm{c}}$ & $74.75 \pm 2.38^{\mathrm{c}}$ & $76.63 \pm 2.33^{\mathrm{bc}}$ & $81.20 \pm 0.92^{\mathrm{ab}}$ & $86.06 \pm 0.80^{\mathrm{a}}$ \\
\hline Mean egg weight, (g) & $12.83 \pm 0.16$ & $12.74 \pm 0.33$ & $12.97 \pm 0.19$ & $12.43 \pm 0.14$ & $12.36 \pm 0.11$ \\
\hline Egg mass / hen / day, (g) & $9.61 \pm 0.12^{\mathrm{bc}}$ & $9.52 \pm 0.29^{c}$ & $9.93 \pm 0.17^{\mathrm{bc}}$ & $10.09 \pm 0.04^{\mathrm{ab}}$ & $10.64 \pm 0.01^{\mathrm{a}}$ \\
\hline $\begin{array}{l}\text { Feed consumed / hen } \\
\text { day, }(\mathrm{g})\end{array}$ & $29.51 \pm 0.76$ & $28.79 \pm 0.22$ & $29.37 \pm 0.55$ & $29.21 \pm 0.42$ & $30.56 \pm 0.49$ \\
\hline $\begin{array}{l}\text { Feed conversion ratio, } \\
\text { (g feed / g egg) }\end{array}$ & $3.07 \pm 0.09$ & $3.03 \pm 0.07$ & $2.96 \pm 0.08$ & $2.90 \pm 0.03$ & $2.87 \pm 0.05$ \\
\hline
\end{tabular}

a, b and $\mathrm{c}$ : Means with different superscript in the same row differ significantly $(\mathrm{P} \leq 0.05)$.

Table (3): Egg quality for laying Japanese quail fed diets supplemented with different levels of Aspergillus awamori (Means $\pm \mathrm{SE}$ )

\begin{tabular}{|l|l|l|l|l|l|}
\hline & & \multicolumn{4}{|c|}{ Tomoko (mg/kg diet) } \\
\cline { 3 - 6 } Parameters & \multirow{2}{*}{ Control } & \multicolumn{1}{|c|}{$\mathbf{2 5 0}$} & \multicolumn{1}{|c|}{$\mathbf{5 0 0}$} & \multicolumn{1}{|c|}{$\mathbf{7 5 0}$} & \multicolumn{1}{|c|}{1000} \\
\cline { 3 - 6 } & & & & & \\
\hline Egg weight, (g) & $13.70 \pm 0.22$ & $14.45 \pm 0.18$ & $14.06 \pm 0.49$ & $14.33 \pm 0.12$ & $14.78 \pm 0.45$ \\
Egg specific gravity & $1.079 \pm 0.01$ & $1.077 \pm 0.02$ & $1.080 \pm 0.02$ & $1.080 \pm 0.02$ & $1.075 \pm 0.02$ \\
Albumen weight, (g) & $7.59 \pm 0.23$ & $7.96 \pm 0.14$ & $7.59 \pm 0.37$ & $7.91 \pm 0.09$ & $8.19 \pm 0.30$ \\
Albumen (\%) & $55.38 \pm 1.21$ & $55.09 \pm 0.91$ & $53.96 \pm 1.74$ & $55.21 \pm 0.42$ & $55.36 \pm 0.49$ \\
Albumen height, (mm) & $2.96 \pm 0.23^{\mathrm{b}}$ & $2.90 \pm 0.12^{\mathrm{b}}$ & $3.50 \pm 0.22^{\mathrm{ab}}$ & $3.03 \pm 0.23^{\mathrm{b}}$ & $3.72 \pm 0.16^{\mathrm{a}}$ \\
Yolk weight, (g) & $4.82 \pm 0.18$ & $5.07 \pm 0.15$ & $5.03 \pm 0.31$ & $4.99 \pm 0.08$ & $5.11 \pm 0.14$ \\
Yolk (\%) & $35.23 \pm 1.24$ & $35.06 \pm 0.75$ & $35.71 \pm 1.68$ & $34.85 \pm 0.48$ & $34.61 \pm 0.43$ \\
Egg shell weight, (g) & $1.28 \pm 0.04^{\mathrm{b}}$ & $1.42 \pm 0.05^{\mathrm{a}}$ & $1.45 \pm 0.03^{\mathrm{a}}$ & $1.42 \pm 0.04^{\mathrm{a}}$ & $1.48 \pm 0.05^{\mathrm{a}}$ \\
Egg shell (\%) & $9.39 \pm 0.36$ & $9.85 \pm 0.29$ & $10.33 \pm 0.27$ & $9.94 \pm 0.23$ & $10.03 \pm 0.29$ \\
Egg shell thickness, (mm) & $0.231 \pm 0.01^{\mathrm{c}}$ & $0.272 \pm 0.02^{\mathrm{ab}}$ & $0.284 \pm 0.01^{\mathrm{a}}$ & $0.258 \pm 0.01^{\mathrm{ab}}$ & $0.255 \pm 0.01^{\mathrm{bc}}$ \\
Yolk index & $386.96 \pm 4.96$ & $402.44 \pm 4.51$ & $413.44 \pm 9.76$ & $418.07 \pm 7.66$ & $427.51 \pm 9.04$ \\
\hline
\end{tabular}

$\mathrm{a}, \mathrm{b}$ and $\mathrm{c}$ : Means with different superscript in the same row differ significantly $(\mathrm{P} \leq 0.05)$. 
Table (4): Yolk total lipids and total cholesterol of laying Japanese quails fed diets supplemented with different levels of Aspergillus awamori (Means $\pm \mathrm{SE}$ )

\begin{tabular}{|l|c|c|c|c|c|}
\hline \multirow{2}{*}{ Parameters } & \multirow{2}{*}{ Control } & \multicolumn{3}{|c|}{ Tomoko (mg/kg diet) } \\
\cline { 3 - 6 } & & $\mathbf{2 5 0}$ & $\mathbf{5 0 0}$ & $\mathbf{7 5 0}$ & 1000 \\
\hline $\begin{array}{l}\text { Yolk total lipids (mg/g } \\
\text { yolk) }\end{array}$ & $347.33 \pm 18.17^{\mathrm{a}}$ & $301.67 \pm 16.41^{\mathrm{ab}}$ & $264.00 \pm 14.41^{\mathrm{b}}$ & $290.33 \pm 10.67^{\mathrm{ab}}$ & $262.00 \pm 9.17^{\mathrm{b}}$ \\
$\begin{array}{l}\text { Yolk total cholesterol } \\
\text { (mg/g yolk) }\end{array}$ & $18.70 \pm 0.28^{\mathrm{a}}$ & $18.63 \pm 0.39^{\mathrm{a}}$ & $18.64 \pm 0.09^{\mathrm{a}}$ & $18.30 \pm 0.23^{\mathrm{a}}$ & $17.00 \pm 0.13^{\mathrm{b}}$ \\
\hline
\end{tabular}

a, $b$ and c: Means with different superscript in the same row differ significantly $(\mathrm{P} \leq 0.05)$.

Table (5): Effect of different levels of Aspergillus awamori on serum blood constituents of laying Japanese quail (Means \pm SE)

\begin{tabular}{|c|c|c|c|c|c|}
\hline \multirow{2}{*}{ Parameters } & \multirow{2}{*}{ Control } & \multicolumn{4}{|c|}{ Tomoko $(\mathrm{mg} / \mathrm{kg}$ diet $)$} \\
\hline & & 250 & 500 & 750 & 1000 \\
\hline Total protein $(\mathrm{g} \%)$ & $3.23 \pm 0.04$ & $3.28 \pm 0.08$ & $3.21 \pm 0.02$ & $3.44 \pm 0.29$ & $3.57 \pm 0.21$ \\
\hline Albumin (g \%) & $2.03 \pm 0.07$ & $2.23 \pm 0.07$ & $2.03 \pm 0.03$ & $2.05 \pm 0.20$ & $2.05 \pm 0.03$ \\
\hline Globulin (g \%) & $1.19 \pm 0.10$ & $1.04 \pm 0.03$ & $1.18 \pm 0.04$ & $1.40 \pm 0.16$ & $1.52 \pm 0.24$ \\
\hline Cholesterol (mg / dl) & $110.30 \pm 9.20$ & $100.07 \pm 5.75$ & $106.33 \pm 2.40$ & $103.50 \pm 0.76$ & $107.33 \pm 6.89$ \\
\hline Total lipids(mg / dl) & $291.67 \pm 16.34$ & $281.00 \pm 4.62$ & $273.00 \pm 21.00$ & $286.33 \pm 4.91$ & $266.00 \pm 4.36$ \\
\hline $\begin{array}{l}\text { Low density lipoprotein (mg } \\
\text { / dl) }\end{array}$ & $23.33 \pm 2.19^{\mathrm{a}}$ & $15.67 \pm 0.67^{b}$ & $16.00 \pm 0.58^{b}$ & $14.67 \pm 0.88^{\mathrm{b}}$ & $17.00 \pm 0.58^{\mathrm{b}}$ \\
\hline $\begin{array}{l}\text { High density lipoprotein (mg } \\
\text { / dl) }\end{array}$ & $71.33 \pm 7.26$ & $78.67 \pm 4.67$ & $66.33 \pm 4.41$ & $73.33 \pm 2.03$ & $79.33 \pm 3.71$ \\
\hline $\begin{array}{l}\text { Total antioxidant capacity } \\
(\mathrm{mM} / \mathrm{L})\end{array}$ & $0.699 \pm 0.04$ & $0.811 \pm 0.03$ & $0.787 \pm 0.03$ & $0.786 \pm 0.03$ & $0.840 \pm 0.03$ \\
\hline $\begin{array}{l}\text { Glutathione peroxidase } \\
(\mathrm{mU} / \mathrm{ml})\end{array}$ & $23.53 \pm 0.62^{\mathrm{d}}$ & $24.77 \pm 0.55^{\mathrm{cd}}$ & $27.83 \pm 1.03^{\mathrm{bc}}$ & $31.00 \pm 0.61^{\mathrm{b}}$ & $35.33 \pm 1.84^{\mathrm{a}}$ \\
\hline $\begin{array}{l}\text { Malondialdehyde } \\
(\mathrm{nmol} / \mathrm{ml})\end{array}$ & $9.61 \pm 0.06^{\mathrm{a}}$ & $9.20 \pm 0.07^{\mathrm{ab}}$ & $8.35 \pm 0.68^{b}$ & $6.62 \pm 0.28^{c}$ & $6.24 \pm 0.33^{c}$ \\
\hline
\end{tabular}

a, b and c: Means with different superscript in the same row differ significantly $(\mathrm{P} \leq 0.05)$. 


\section{REFERENCES}

Abdel-Azeem, F. A.; Nematallah, G. M. and Ibrahim Faten, A. A. (2005). Effect of dietary protein level with some natural biological feed additives supplementation on productive and physiological performance of Japanese quail. Egypt. Poult. Sci. Vol. 25 (II): 497525 .

Abo-Mahara, M. (2015). Effect of thyme and garlic essential oils and their combination on the performance of Japanese quail. $\mathrm{Ph}$. D. Thesis, Faculty of Agric. (Saba Basha), Alexandria Univ., Alexandria, Egypt.

Alloui, M. N.; Szczurek, W. and Świątkiewicz, S. (2013). The usefulness of prebiotics and probiotics in modern poultry nutrition: review Ann. Anim. Sci., 1 (2013), pp. 17-32.

A. O. A. C. (2005). Official Methods of Analysis. 18th Edn., Association of Official Analytical Chemists, Washington, DC., USA.

Asli, M. M.; Hosseini, S. A.; Lotfollahian, H. and Shariatmadari, F. (2007). Effect of Probiotics, Yeast, Vitamin $\mathrm{E}$ and Vitamin C Supplements on Performance and Immune Response of Laying Hen During High Environmental Temperature. International Journal of Poultry Science 6 (12): 895-900.

Awaad, M. H. H.; Amer, H. M.; Zohair, G. A.; Atta, A.; Elmeniawy, M. and Elkholy, M. A. (2005). Effect of Pediococcus acidilactici on layer hens serum/yolk cholesterol, egg quality, and intestinal/egg shedding of Salmonella enteritidis. Vet. Med. J. Giza 53:489-499.

Balevi, T.; An, U. S. U.; Coskun, B.; Kurtoglu, V. and Etingul, I. S. (2001). Effect of dietary probiotic on performance and humoral immune response in layer hens. Br. Poult. Sci., 42: 456-461.

Bigelis, R. and Lasure, L. (1987). "Fungal enzymes and primary metabolites used in food processing," in Food and Beverage Mycology, Beuchat LR, Ed., pp. 473-516, Avi, Westport, Conn, USA, $2^{\text {nd }}$ edition.

Bremer, J. (1983). Carnitine - metabolism and functions. Physiol. Rev., 63, 1420-1480.

Burkholder, K. M.; Thompson, K. L.; Einstein, M. E.; Applegate, T. J. and Patterson, J. A. (2008). Influence of stressors on normal intestinal microbiota, intestinal morphology, and susceptibilityto Salmonella Enteritidis colonization in broilers. Poult. Sci. 87:1734-1741.

Chen, Y. C. and Chen, T. C. 2003. Effects of commercial probiotic or prebiotic supplementation on production, size and quality of hens egg. Poult. Sci., 82: 330 .

Deng, W.; Dong, X. F.; Tong, J. M. and Zhang, Q. (2012). The probiotic Bacillus licheniformisameliorates heat stress-induced impairment of egg production, gut morphology, and intestinal mucosal immunity in laying hens. Poult. Sci. 91:575-582.

Duncan, D. B. (1955). Multiple range and multiple F test, Biometrics, 11: 1-42.

Durant, J. A.; Corrier, D. E.; Byrd, J. A.; Stanker, L. H. and Ricke, S. C. (1999). Feed deprivation affects crop environment and modulates Salmonella enteritidiscolonization and invasion of leghorn hens. Appl. Environ. Microbiol. 65:1919-1923.

Eid, Y.; Ebeid, T.; Moawad, M. and ElHabbak, M. (2008). Reduction of dexamethasone-induced oxidative stress and lipid peroxidation in laying hens by dietary vitamin E supplementation. Emirates Journal of Food and Agriculture, 20: 28-40.

Eid, Y.; Ohtsuka, Z. and Hayashi, K. (2003). Tea polyphenols reduce 
glucocorticoid-induced growth inhibition and oxidative stress in broiler chickens. British Poultry Science, 44: 350-356.

Elphick, D. A. and Mahida, Y. R. (2005). Paneth cells: Their role in innate immunity and inflammatory disease. Gut 54:1802-1809.

Endo, A. (1985). "Compactin (ML-236B) and related compounds as potential cholesterol-lowering agents that inhibit HMG-CoA reductase," Journal of Medicinal Chemistry, vol. 28, no. 4, pp. 401-405,

Ercal, N.; Gurer-Orhan, H. and AykinBurns, N. (2001). Toxic metals and oxidative stress part I: mechanisms involved in metal-induced oxidative damage. Current Topics in Medicinal Chemistry, 1: 529-539.

Folch, J.; Less, M. and Solane Stanley, G. H. (1956). A simple method for the isolation andpurification of total lipid from animal tissues. J. Bio. Chem., 226: 497-509.

Fuller, R. (1989). Probiotics in man and animals. J. Appl. Bacteriol. 66:365378.

Guclu, B. K. (2011). Effects of probiotic and prebiotic (mannanoligosaccharide)

supplementation on performance, egg quality and hatchability in quail breeders. Ankara Universitesi Veteriner Fakultasi Dergisi, 58: 2732.

Halliwell, B. E.; and Gutteridge, J. M. C. (1989). Lipid peroxidation: a radical chain reaction. In: Free Radicals in Biology and Medicine, 2nd ed. Oxford University Press, New York, NY, pp. 188-218.

Higgins, S. E.; Higgins, J. P.; Wolfenden, A. D.; Henderson, S. N.; TorresRodriguez, A.; Tellez, G. and Hargis, B. (2008). Evaluation of a Lactobacillus-based probiotic culture for the reduction of Salmonella
Enteritidis in neonatal broiler chicks. Poult. Sci. 87:27-31.

Hosseini, S. A.; Lotfollahian, H.; Kamyab, A. and Mahdavi, A. (2006). Study on the effect of yeast (Saccharomyces cerevisiae SC47) utilization on the commercial layer hen's performance. Pak. J. Biol. Sci., 9: 2346-2349.

Humphrey, T. (2006). Are happy chickens safer chickens? Poultry welfare and disease susceptibility. Br. Poult. Sci. 47:379-391.

Kaminishi, Y.; Egusa, J. and Kunimoto, M. (1999). Antioxidant production from several xerophilous fungi used in "Katsuobushi" molding. Journal of National Fisheries University, 47: 113-120.

Khan, R. U.; Naz, S., Nikousefat, Z., Selvaggi, M.; Laudadio, V. and Tufarelli, V. (2012). Effect of ascorbic acid in heat-stressed poultry. World's Poultry Science Journal, 68: 477-490.

Kurtoglu, V.; Kurtoglu, F.; Seker, E.; Coskun, B.; Balevi T. and Polat, E. S. (2004). Effect of probiotic supplementation on laying hen diets on yield performance and serum and egg yolk cholesterol. Food Addit. Contam., 21: 817-23.

Li, W. F.; Rajput, I. R.; Xu, X.; Li, Y. L.; Lei, J.; Huang, Q. and Wang, M. Q. (2011). Effect of probiotic (Bacillus subtillis) on laying performance, blood biochemical properties and intestinalmicroflora of shaoxing duck. Inter. J. Poult. Sci. $10 ; 583-589$.

Lin, H., H. C. Jiao, J. Buyseand E. Decuypere (2006). Strategies for preventing heat stress in poultry. World's Poultry Science Journal, 62: 71-86.

Luadicina, D. C. and Marnett, L. J. (1990). Enhancement of hydroperoxide-dependent lipid peroxidation in rat liver microsomes 
by ascorbic acid. Arch. Biochem. Biophys., 278: 73-80.

Mahdavi, A. H.; Rahmani, H. R. and Pourreza, J. (2005). Effect of Probiotic Supplements on Egg Quality and Laying Hen's Performance. Int. J. Poult. Sci., 4: 488-492.

Mikulski, D.; Jankowski, J.; Naczmanski, J.; Mikulska, M. and Demey, V. (2012). Effects of dietaryprobiotic (Pediococcus acidilactici) supplementation on performance, nutrient digestibility, egg traits, egg yolk cholesterol and fatty acid profile in laying hens. Poult. Sci., 91: 26912700.

Mountzouris, K. C.; Tsirtsikos, P.; Kalamara, E.; Nitsch, S.; Schatzmayr; G. and Fegeros, K. (2007).Evaluation of the efficacy of a probiotic containing Lactobacillus, Bifidobacterium, Enterococcus, and Pediococcus strains in promoting broiler performance and modulating cecalmicroflora composition and metabolic activities. Poult. Sci. 86:309-317.

NRC (National Research Council) (1994). Nutrient requirements of poultry. Nutrient Requirements of Domestic Animals. $9^{\text {th }}$ rev. ed . Natl. Acad. Sci., Washington, D.C.

Okada, S. (1996). Iron-induced tissue damage and cancer: the role of reactive oxygen species-free radicals. Pathology International, 46: 311332 .

Pinto, E.; Sigaud-Kutner, T. C. S.; Leitão, M. A. S.; Okamoto, O. K.; Morse, D. and Colepicolo, P. (2003). Heavy metal-induced oxidative stress in algae. Journal of Phycology, 39: 1008-1018.

Quinteiro-Filho, W. M.; Ribeiro, A.; Ferraz-de-Paula, V.; Pinheiro, M. L., M. L.; Sakai, M.; Sa, L. R.; Ferreira, A. J. and Palermo-Neto, J. (2010). Heat stress impairs performance parameters, induces intestinal injury, and decreases macrophage activity in broiler chickens. Poult. Sci. 89:1905-1914.

Sahin, K.; Sahin, N.; Kucuk, O.; Hayirili, A. and Prasad, A. S. (2009). Role of dietary zinc in heat- stressed poultry: Areview. Poultry Science, 88: 21762183.

Sahin, K. and Kucuk, O. (2003). Heat stress and dietary vitamin supplementation of poultry diets. Nutr. Abstr. Rev. Ser. B Livest. Feed Feeding 73, 41R-50R.

Saleh, A. A., Eid, Y.; Ebaid, T.; Ohtsuka A. and Hayashi, K. (2012).“The modification of the muscle fatty acid profile by dietary supplementation with Aspergillus awamori in broiler chickens," British Journal of Nutrition, vol. 108, pp. 1596-1602.

SAS Institute (1996). SAS ${ }^{\circledR}$ User's Guide: Statistics. SAS Institute Inc., Cary, NC.

Simeamelak, M.; Solomon, D. and Taye, T. (2013). The effect of effective microorganisms on production and quality performance of Rhode Island Red layers. International Journal of Livestock Production Vol. 4(2): 2229.

Sohail, M. U.; Ijaz, A. Yousaf,M. S.; Ashraf,K.; Zaneb, H.; Aleem, M. and Rehman, H. (2010). Alleviation of cyclic heat stress in broilers by dietary supplementation of mannanoligosaccharide and Lactobacillusbased probiotic: Dynamics of cortisol, thyroid hormones, cholesterol, C-reactive protein, and humoral immunity. Poult. Sci. 89:1934-1938.

Sohail, M. U.; Hume, M. E.; Byrd, J. A.; Nisbet, D. J.; Ijaz, A.; Sohail, A.;S habbir and, M. Z. and Rehman, $H$. (2012). Effect of supplementation of prebiotic mannan-oligosaccharides and probiotic mixture on growth performance of broilers subjected to 
chronic heat stress. Poult. Sci. Yousefi, M. and Karkoodi, K. (2007). 91:2235-2240.

Surai, P. F. (2002). Natural antioxidants in avian nutrition and reproduction. Nottingham University Press, Nottingham, UK.

Effect of probiotic thepax and Saccharomyces cerevisiae supplementation on performance and egg quality of laying hens. Int. Poult. Sci., 6: 52-54

Valko, M.; Leibfritz, D.; Moncol, J.; Cronin,_M. T. D.; Mazur, M. and Telser, J. (2007). Free radicals and antioxidants in normal physiological functions and human disease. The International Journal of Biochemistry \& Cell Biology, 39: 44-84. 2007.

Washburn, K. W. and Nix, D. F. (1974). A rapid technique for extraction of yolk cholesterol. J. Poult. Sci. 53, 1118-1122.

Yokoyama, K.; Wang, L.; Miyaji, M. and Nishimura, K. (2001). Identification, classification and phylogeny of the Aspergillus section Nigri inferred from mitochondrial cytochrome $b$ gene. FEMS Microbiology Letters, 200: 241-246.

Zeweil, H. S.; Abd El-Rahman,M. H.; Zahran, S. M.; Dosoky,W. M. and Abo-Mahara, M. (2015). Effect of essential oil of garlic and probiotic on performance, carcass and lipid metabolism of growing japanese quail. World's Poultry Science Journal, Vol. 71: Supplement 1: 173.

Zeweil, H. S.; Basiouny, M. and Soha

Farag (2010). Influence of supplemental lactose as prebiotic and super bio-buds as probiotic on Japanese quail laying hens performance, egg quality, digestion, villi height and intestinal microbiology. XIII European Poultry Conference, 23-27, August 2010, Tours,

France. 


\title{
تأثير مستويات مختلفه من الاسبرجلس أوامورى كبروبيوتك فى علائق السمان البياض على الانتاج

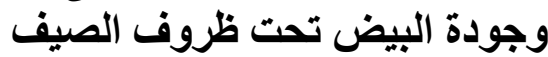

\author{
حسن زويل" - يحيى زكريا عيد** ـ سليمان زهران" - وليد دسوقى *ـ سالمه هاثم أبوحفصه***ـ آمال

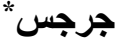

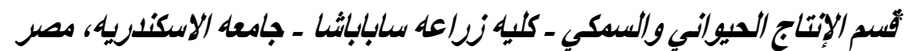

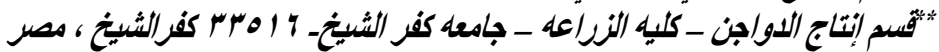

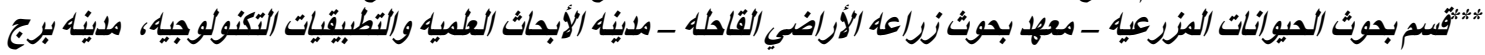

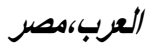

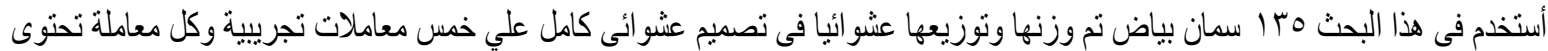

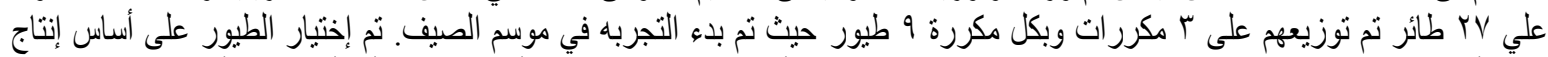

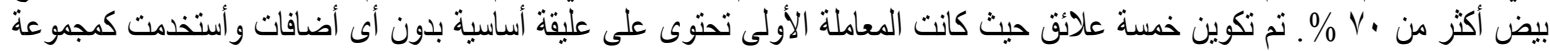

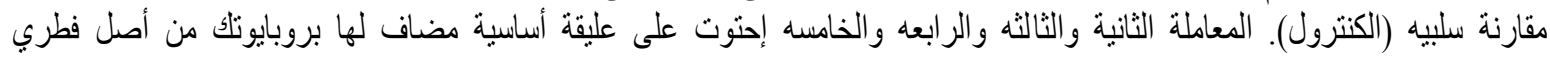
(Tspergillus awamori (Tomoko ${ }^{\circledR}$ )

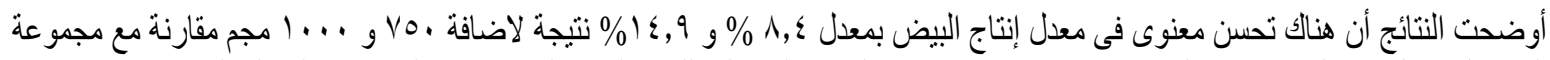

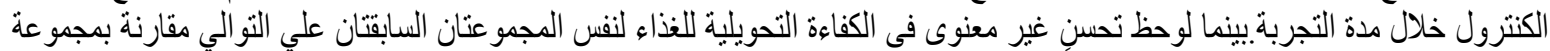

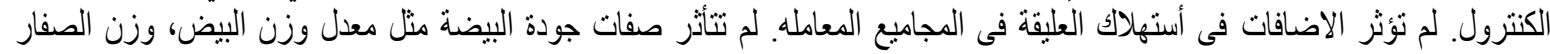

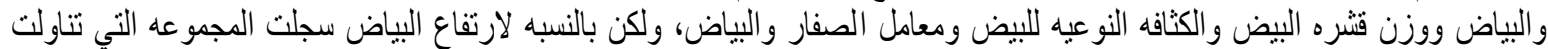

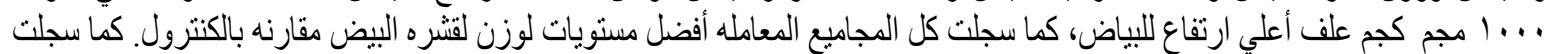

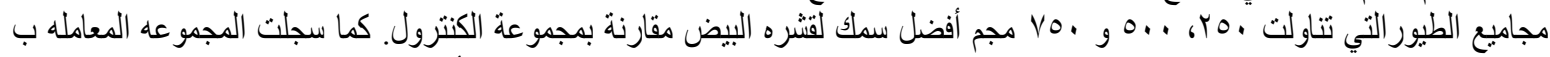

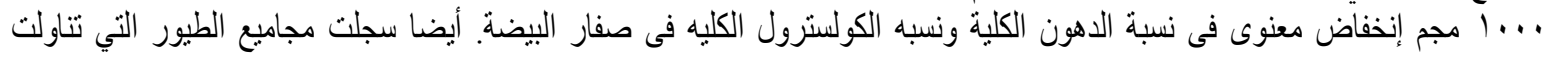

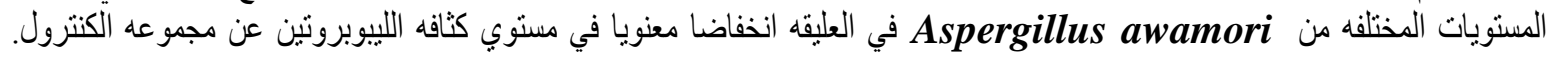

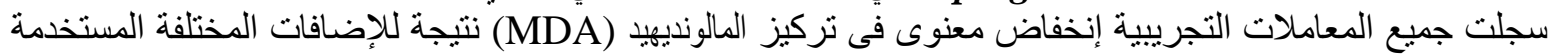

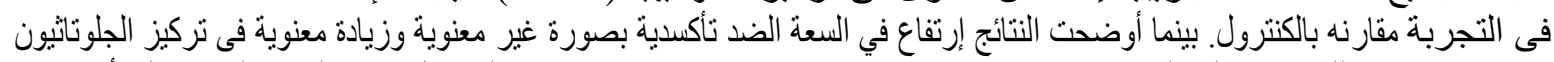

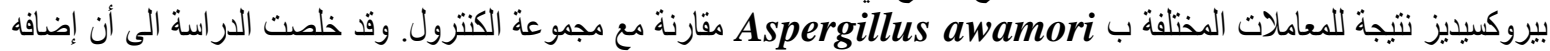
Aspergillus awamori أدي لتعزيز الصفات المناعيه والصفات الضد تأكسدية للسمان تحت ظروف الصيف الحار. 